\title{
Association of Plasmid Typing to Biotyping and Antibiotyping in the Characterization of Outbreaks by Acinetobacter baumannii.
}

\author{
Maria Cristina Bronharo Tognim ${ }^{1^{*}}$, Luiz Carlos Jabur Gaziri², Marilda Carlos Vidotto ${ }^{3}$, \\ Marcia Regina Perugini ${ }^{3}$. \\ ${ }^{1}$ Departamento de Análises Clinicas, Universidade Estadual de Maringá, 87020 -900, Maringá, PR, Brasil; ${ }^{2}$ \\ Departamento de Ciências Fisiológicas; ${ }^{3}$ Departamento de Patologia Geral, Universidade Estadual de Londrina, \\ 86051-970, Londrina, PR, Brasil.
}

\begin{abstract}
During an outbreak at an University Hospital, from April to September, in 1994, sixteen strains of Acinetobacter baumannii were isolated from patients and one strain from an enteral solution. We afterwards analyzed the outbreak by means of plasmid typing, antibiotic resistance typing and biotyping. Two main plasmid profiles were identified. Twelve strains belonged to biotype 2, and five to biotype 19. Susceptibility to amikacin and to carbenicillin allowed classification of the strains into two groups. The results show that association of those three typing methods allowed the differentiation of what was at first considered as a single outbreak into two apparently unrelated outbreaks.
\end{abstract}

Key words: Acinetobacter baumannii; outbreak; plasmid, biotyping.

\section{INTRODUCTION}

Strains of the genus Acinetobacter have recently been recognized as agents of nosocomial infections that represent a significant problem in many countries (Muller-Serieys et al., 1989; Ramphal \& Kluge, 1979). This genus comprises at least 17 genomic species (Tjernberg \& Ursing, 1989), and the species A. baumannii has been the one most frequently isolated from patients bearing hospital-acquired Acinetobacter infections (Beck-Sagué et al., 1990; Oliveira et al., 1993). The route of transmission in most outbreaks by these bacteria includes the contamination of devices such as intravenous catheters, prosthetic valves, respiratory equipment used in conjunction with endotracheal tubes or tracheotomy, and also bedding material (Beck-Sagué et al., 1990 ; Harststein et al., 1988 ; Sherertz \& Sullivan, 1985; Weernink et al., 1995).

Various typing methods have been used for the identification of pathogenic isolates of
Acinetobacter, such as biotyping (Oliveira et al., 1993; Bouvet \& Grimont, 1987; Bouvet et al., 1990), serotyping (Traub \& Spohr, 1994), antibiotic resistance typing (Vila et al., 1989), phage typing (Bouvet et al., 1990; SantosFerreira et al., 1984), and envelope protein profiles (Bouvet et al., 1990; Dijkshoorn et al., 1989). However, all these methods evaluate the expression of phenotypic characters which can be affected by many environmental factors; genotyping methods, on the other hand, are more stable but more expensive and timeconsuming. Among the genotyping methods, plasmid typing (Vila et al., 1989; Seifert et al., 1994a), ribotyping (Gerner-Smidt, 1992; Seifert \& Gerner-Smidt, 1995), analysis of restriction fragment length polymorphisms by pulsed-field gel electrophoresis (Seifert \& Gerner-Smidt, 1995; Gouby et al., 1992), and PCR fingerprinting (Graser et al., 1993; Reboli et al., 1994) have been used for the identification of Acinetobacter. Since biotyping and antibiotic resistance typing are routinely performed at

\footnotetext{
* Author for correspondence
} 
hospital laboratories, and given that plasmid typing is the easiest and least expensive of the genotyping methods, the purpose of this study was to determine whether an association of these three methods could allow an adequate epidemiologic characterization of an outbreak of infection by Acinetobacter $s p$.

\section{MATERIALS AND METHODS}

Bacterial strains: Seventeen Acinetobacter strains were isolated during an outbreak which occurred from April to September, in 1994, at the University Hospital, in Londrina, Brazil. Sexteen of them were isolated from clinical specimens of 14 hospitalized patients in intensive care unit, one isolated from nursery patient, and another strain from an enteral solution. The isolates were identified as $A$. baumannii according to Bouvet \& Grimond (1987) and maintained either on Luria Bertani (LB) broth at $-20^{\circ} \mathrm{C}$ or on LB slants agar at room temperature. The strain ATCC 14606 was used as control.

Biotying of $A$. baumannii strains: Utilization of six carbon sources (citraconate, levulinate, Lphenylalanine, phenylacetate, 4hydroxybenzoate and L-tartarate), allowed the identification of biotypes, as described by Bouvet \& Grimond (1987).

Antibiotic susceptibility: Susceptibility to 15 antibiotics was determined by the disk diffusion method (Bauer et al., 1966), on Müeller-Hinton agar (Difco). The following disks were used: Nalidixic acid $(30 \mu \mathrm{g})$; Amikacin $(30 \mu \mathrm{g})$, Ampicillin $(10 \mu \mathrm{g})$; Carbenicillin $(100 \mu \mathrm{g})$; Cephalothin (30 $\mu \mathrm{g})$; Cefotaxime $(30 \mu \mathrm{g})$; Ceftazidime (30 $\mu \mathrm{g})$; Chloranphenicol $(30 \mu \mathrm{g})$; Gentamicin $(10 \mu \mathrm{g})$; Imipenem $(10 \mu \mathrm{g})$; Perfloxacin (5 $\mu \mathrm{g})$; Tobramycin (10 $\mu \mathrm{g})$; Sulfazotrin $(25 \mu \mathrm{g})$; Tetracycline $(30 \mu \mathrm{g})$. Additionaly, the MIC was determined by dilution test agar method according to Sahm \& Washington II (1991).

Plasmid analysis: Plasmid DNA was isolated from the 17 strains by the alkaline method of Kado \& Liu (1981), with some modifications.
Cells were grown overnight in $3 \mathrm{ml}$ of LB broth medium at $37^{\circ} \mathrm{C}$ and $1.5 \mathrm{ml}$ was spun down at $10.000 \mathrm{x} \mathrm{g}$ for $1 \mathrm{~min}$. The pellet obtained was washed in $1 \mathrm{ml}$ of TE buffer $(50 \mathrm{mM}$ Tris- $\mathrm{HCl}$, $10 \mathrm{mM}$ EDTA - $\mathrm{pH}$ 8.0). After centrifugation the cells were resuspended in $50 \mu \mathrm{l}$ of TE, and $400 \mu \mathrm{l}$ of lysing solution (50 mM Tris and 3\% SDS - $\mathrm{pH}$ 12.45) were added. The solution was mixed by brief agitation and incubated in a water bath at $60^{\circ} \mathrm{C}$ for $30 \mathrm{~min}$. The lysate was subsequently incubated on ice water, and $20 \mu \mathrm{l}$ of $2 \mathrm{M}$ Tris- $\mathrm{HCl}(\mathrm{pH}$ 7.0) were added. The extraction was made by addition of an equal volume of phenol-chloroform solution. After centrifugation as above for $10 \mathrm{~min}, 60 \mu \mathrm{l}$ of aqueous phase were mixed with loading buffer and applied to a vertical agarose gel $(0.7 \%)$ for electrophoresis at $60 \mathrm{~V}$. The plasmids were also extracted as described by Harstein et al. (1990). The isolates were grown on LB agar plates at $37^{\circ} \mathrm{C}$ for 24 hours. Cells from one quarter of the plate were resuspended twice in $1.0 \mathrm{ml}$ of $2.5 \mathrm{M}$ $\mathrm{NaCl}, \quad 10 \mathrm{mM}$ EDTA (pH 8.0). After centrifugation, $900 \mu \mathrm{l}$ of $20 \%$ sucrose, $50 \mathrm{mM}$ Tris, $10 \mathrm{mM}$ EDTA (pH8.0) and $200 \mu \mathrm{l}$ of lysozyme $(10 \mathrm{mg} / \mathrm{ml})$ were added to the pellet and incubated at $30^{\circ} \mathrm{C}$ for $30 \mathrm{~min}$. After incubation, $500 \mu \mathrm{l}$ of $2.5 \mathrm{M} \mathrm{NaCl}, 10 \mathrm{mM}$ EDTA (pH 8.0) and a lysis solution containing $250 \mu \mathrm{l}$ of $0.5 \%$ mixed alkyltrimethilamonium bromide (ATAB) and $50 \mu \mathrm{l}$ of $10 \%$ Triton X100 were added to each test tube. The resulting lysate was incubated in a water bath at $56^{\circ} \mathrm{C}$ for $15 \mathrm{~min}$ and then centrifuged at $10.000 \mathrm{x}$ g for 30 min. To the supernatant was added $1 \mu \mathrm{l}$ of RNAse solution $(10 \mathrm{mg} / \mathrm{ml})$ and incubated at $37^{\circ} \mathrm{C}$ for $30 \mathrm{~min}$. Protein was eliminated by two washes with phenol-chloroform-isoamyl alchool (25:24:1) solution. Finally, plasmid DNA was precipitated by addition of an equal volume of ice-cold isopropanol. The precipitate was spun down for $20 \mathrm{~min}$ at $10.000 \mathrm{x} \mathrm{g}$, dried and then resuspended in $60 \mu \mathrm{l}$ of the TE buffer $(10 \mathrm{mM}$ Tris, 1mM EDTA - pH 8.0). Electrophoresis was performed on a horizontal gel containing $0.8 \%$ agarose in TEB. Samples $(30 \mu \mathrm{l})$ were mixed with running dye buffer $(8 \mu \mathrm{l})$, loaded onto the agarose gel (1\%), and run for $12 \mathrm{~h}$ at 40 V. Gels were stained with ethidium bromide and photographed under a U.V. lamp. The following 
plasmids were used as markers of molecular mass: pSa (23 MDa), RP4 (34 MDa), JPN11 (66 Mda), R27 (110 Mda), plus the standard plasmids from E.coli V517.

\section{RESULTS}

Antibiotic susceptibility: All studied A.baumannii strains were susceptible to imipenem $(\leq 4 \mu \mathrm{g} / \mathrm{ml})$, and resistant to ampicillin, cephalothin, chloramphenicol, ceftazidime $(\geq 32 \mu \mathrm{g} / \mathrm{ml})$, and trimethoprin, gentamicin $(\geq 16 \mu \mathrm{g} / \mathrm{ml})$. The A. baumannii strains that showed differents antibiotic susceptibilities pattern, are showed at table I. Excepting imipenem, the matrix of 15 antimicrobial agents versus 17 strains, with 255 entries, presented 195 (76.5\%) occurrences of resistance, 38 (14.9\%) occurrences of intermediate resistance, and $22(8.6 \%)$ occurrences of susceptibility; therefore, most of the strains were resistant to most of the antibiotics tested. Fifty percent $(11 / 22)$ of the occurrences of susceptibility corresponded to tetracycline, that is, $64.7 \%$ $(11 / 17)$ of the strains were susceptible to tetracycline. Resistance to amikacin and to carbenicillin allowed the classification of strains into two patterns. Strains that were either susceptible or intermediate-resistant to amikacin and carbenicillin were classified as belonging to pattern A; strains that were resistant to those antibiotics were classified as pattern B (Table $1)$.

Biotyping: Two biotypes of A. baumannii, 2 and 19, were isolated from patients; the strain isolated from an enteral solution belonged to biotype 2 (Table 2).

Table 1. Antibiotic Susceptibilities of Acinetobacter baumannii strains.

\begin{tabular}{cccccccccc}
\hline Strain & \multicolumn{7}{c}{ MIC concentration $(\mu \mathrm{g} / \mathbf{m l}) /$ Antibiotic Susceptibilities pattern } \\
& AM & CAB & CFT & CIP & NAL & PEF & SUL & TOB & TET \\
\hline $\mathbf{0 1}$ & $>64(\mathrm{R})$ & $>64(\mathrm{R})$ & $>64(\mathrm{R})$ & $1<4(\mathrm{I})$ & $<16(\mathrm{~S})$ & $4<16(\mathrm{I})$ & $>512(\mathrm{R})$ & $>16(\mathrm{R})$ & $<4(\mathrm{~S})$ \\
$\mathbf{0 6}$ & $<16(\mathrm{~S})$ & $16<64(\mathrm{I})$ & $>64(\mathrm{R})$ & $1<4(\mathrm{I})$ & $<16(\mathrm{~S})$ & $4<16(\mathrm{I})$ & $>512(\mathrm{R})$ & $>16(\mathrm{R})$ & $<4(\mathrm{~S})$ \\
$\mathbf{0 9}$ & $<16(\mathrm{~S})$ & $16<64(\mathrm{I})$ & $>64(\mathrm{R})$ & $1<4(\mathrm{I})$ & $<16(\mathrm{~S})$ & $4<16(\mathrm{I})$ & $>512(\mathrm{R})$ & $>16(\mathrm{R})$ & $<4(\mathrm{~S})$ \\
$\mathbf{1 0}$ & $16<64(\mathrm{I})$ & $16<64(\mathrm{I})$ & $>64(\mathrm{R})$ & $1<4(\mathrm{I})$ & $>32(\mathrm{R})$ & $4<16(\mathrm{I})$ & $>512(\mathrm{R})$ & $>16(\mathrm{R})$ & $<4(\mathrm{~S})$ \\
$\mathbf{1 1}$ & $16<64(\mathrm{I})$ & $16<64(\mathrm{I})$ & $>64(\mathrm{R})$ & $1<4(\mathrm{I})$ & $>32(\mathrm{R})$ & $4<16(\mathrm{I})$ & $>512(\mathrm{R})$ & $>16(\mathrm{R})$ & $<4(\mathrm{~S})$ \\
$\mathbf{1 2}$ & $<16(\mathrm{~S})$ & $16<64(\mathrm{I})$ & $>64(\mathrm{R})$ & $1<4(\mathrm{I})$ & $<16(\mathrm{~S})$ & $4<16(\mathrm{I})$ & $256<512(\mathrm{I})$ & $>16(\mathrm{R})$ & $<4(\mathrm{~S})$ \\
$\mathbf{1 3}$ & $<16(\mathrm{~S})$ & $16<64(\mathrm{I})$ & $8<64(\mathrm{I})$ & $<1(\mathrm{~S})$ & $<16(\mathrm{~S})$ & $<4(\mathrm{~S})$ & $256<512(\mathrm{I})$ & $4<16(\mathrm{I})$ & $<4(\mathrm{~S})$ \\
$\mathbf{1 5}$ & $>64(\mathrm{R})$ & $>64(\mathrm{R})$ & $>64(\mathrm{R})$ & $1<4(\mathrm{I})$ & $>32(\mathrm{R})$ & $4<16(\mathrm{I})$ & $256<512(\mathrm{I})$ & $4<16(\mathrm{I})$ & $<4(\mathrm{~S})$ \\
$\mathbf{1 6}$ & $>64(\mathrm{R})$ & $>64(\mathrm{R})$ & $>64(\mathrm{R})$ & $1<4(\mathrm{I})$ & $16<32(\mathrm{I})$ & $4<16(\mathrm{I})$ & $>512(\mathrm{R})$ & $>16(\mathrm{R})$ & $<4(\mathrm{~S})$ \\
$\mathbf{1 7}$ & $>64(\mathrm{R})$ & $>64(\mathrm{R})$ & $>64(\mathrm{R})$ & $>4(\mathrm{R})$ & $>32(\mathrm{R})$ & $>16(\mathrm{R})$ & $>512(\mathrm{R})$ & $>16(\mathrm{R})$ & $<4(\mathrm{~S})$ \\
$\mathbf{1 8}$ & $>64(\mathrm{R})$ & $>64(\mathrm{R})$ & $>64(\mathrm{R})$ & $>4(\mathrm{R})$ & $>32(\mathrm{R})$ & $>16(\mathrm{R})$ & $>512(\mathrm{R})$ & $>16(\mathrm{R})$ & $<4(\mathrm{~S})$ \\
$\mathbf{1 9}$ & $>64(\mathrm{R})$ & $>64(\mathrm{R})$ & $>64(\mathrm{R})$ & $1<4(\mathrm{I})$ & $>32(\mathrm{R})$ & $4<16(\mathrm{I})$ & $>512(\mathrm{R})$ & $4<16(\mathrm{I})>16(\mathrm{R})$ \\
$\mathbf{2 1}$ & $>64(\mathrm{R})$ & $>64(\mathrm{R})$ & $>64(\mathrm{R})$ & $>4(\mathrm{R})$ & $>32(\mathrm{R})$ & $>16(\mathrm{R})$ & $>512(\mathrm{R})$ & $>16(\mathrm{R})$ & $4<16(\mathrm{I})$ \\
$\mathbf{2 2}$ & $>64(\mathrm{R})$ & $>64(\mathrm{R})$ & $>64(\mathrm{R})$ & $>4(\mathrm{R})$ & $>32(\mathrm{R})$ & $>16(\mathrm{R})$ & $>512(\mathrm{R})$ & $>16(\mathrm{R})>16(\mathrm{R})$ \\
$\mathbf{2 3}$ & $>64(\mathrm{R})$ & $>64(\mathrm{R})$ & $>64(\mathrm{R})$ & $>4(\mathrm{R})$ & $>32(\mathrm{R})$ & $>16(\mathrm{R})$ & $>512(\mathrm{R})$ & $>16(\mathrm{R})>16(\mathrm{R})$ \\
$\mathbf{2 4}$ & $>64(\mathrm{R})$ & $>64(\mathrm{R})$ & $>64(\mathrm{R})$ & $>4(\mathrm{R})$ & $>32(\mathrm{R})$ & $>16(\mathrm{R})$ & $>512(\mathrm{R})$ & $>16(\mathrm{R})>16(\mathrm{R})$ \\
$\mathbf{E n}$ & $>64(\mathrm{R})$ & $>64(\mathrm{R})$ & $>64(\mathrm{R})$ & $1<4(\mathrm{I})$ & $16<32(\mathrm{I})$ & $4<16(\mathrm{I})$ & $>512(\mathrm{R})$ & $>16(\mathrm{R})>16(\mathrm{R})$ \\
\hline
\end{tabular}

AM=amikacin; $\mathbf{C A B}=$ carbenicillin; $\mathbf{C F T}=$ cefotaxime; $\mathbf{C I P}=$ Ciprofloxacin; NAL=nalidixic acid; $\mathbf{P E F}=$ perfloxacim; SFZ=sulfametoxazole; TET=tetracyclin; TB=tobramycin .

$\mathbf{R}=$ Resistent; I=Intermediate; $\mathbf{S}=$ Susceptible.

$\mathbf{E n}=$ strain isolated from enteral solution

Plasmid analysis: Plasmids were found in $\mathbf{1 5}$ $(88.2 \%)$ strains with an average of 3 plasmids per strains; their relative molecular mass ranged from 2 to $66 \mathrm{MDa}$ (Table 1). No plasmids were 
found in $2(11.8 \%)$ strains. Figs.1A and 2 show the profiles of plasmids isolated from strains of A. baumannii by the method of Kado \& Liu (1981). Fig. 1B shows low molecular mass plasmids isolated from strains of A. baumannii by the method of Harstein et al. (1990). Based on the detection of the $66 \mathrm{MDa}$ plasmid, two plasmid profiles were assigned to the $A$. baumannii strains: plasmid profile I was assigned to strains carrying the $66 \mathrm{MDa}$ plasmid, and profile II was assigned to strains carrying only low (less than $13 \mathrm{Mda}$ ) molecular mass plasmids.

Typing of $\boldsymbol{A}$. baumannii: Table 2 presents a correlation among the typing results, sampling site, and period of strain isolation. Six strains were isolated during April, five of them from catheter tips and one from skin secretion; all those strains belonged to biotype 2 and, with the single exception of one plasmidless strain, they all presented plasmid profile II (absence of the 66 Mda plasmid) and antibiotic resistance pattern A. Eleven strains isolated from June to September belonged to biotypes 2 and 19 and, excepting one plasmidless strain, all of them presented plasmid profile I(presence of the 66 Mda plasmid) and antibiotic resistance pattern B. The ratio of strains isolated from skin to isolates from catheter tips changed from 0.2 (1/5) during April to 1.2 (6/5) during June to September.

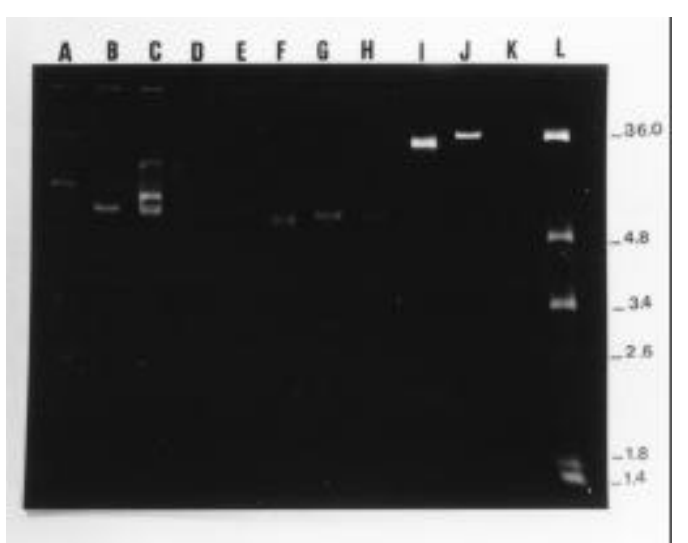

Fig. 1A. Agarose gel electrophoresis of Acinetobacter baumannii plasmid DNA extracted by the method of Kado \& Liu (1981). Lane A: strain from enteral solution; Lanes B to $\mathrm{H}$ : strains $1,6,9,10,11,12$, and 13 respectively; Lanes I to $\mathrm{L}$, standard plasmids: RP4 (34MDa), JPN11 (66 MDa), R27 (110MDa), V517 (standard plasmids from Escherichia coli 517 ).

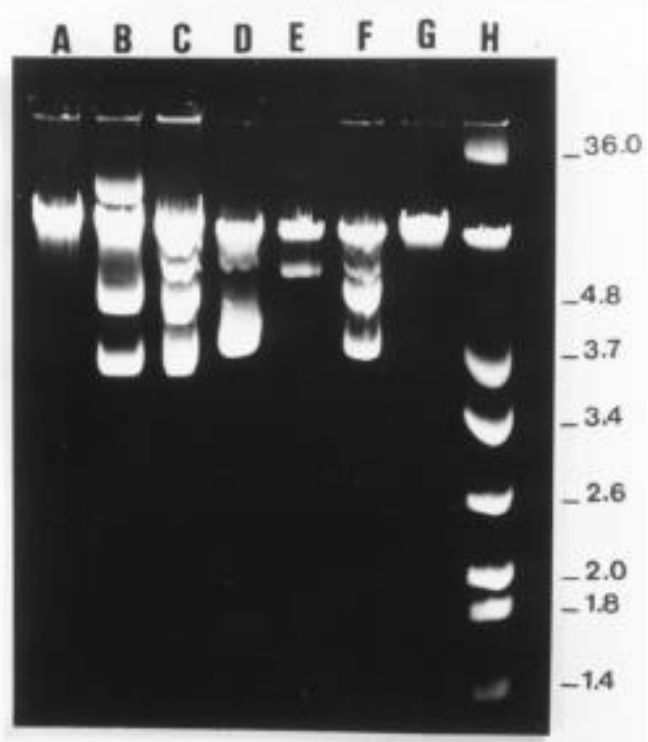

Fig. 1B. Agarose gel electrophoresis of $A$. baumannii plasmid DNA extracted by the method of Harstein et al. (1990). Lane B: strain from enteral solution; Lanes $\mathrm{A}$, and $\mathrm{C}$ to $\mathrm{G}$ : strains $1,6,9,10,11,12$, and 13 respectively. Lane $\mathrm{H}$ : molecular mass marker from E. coli V517 


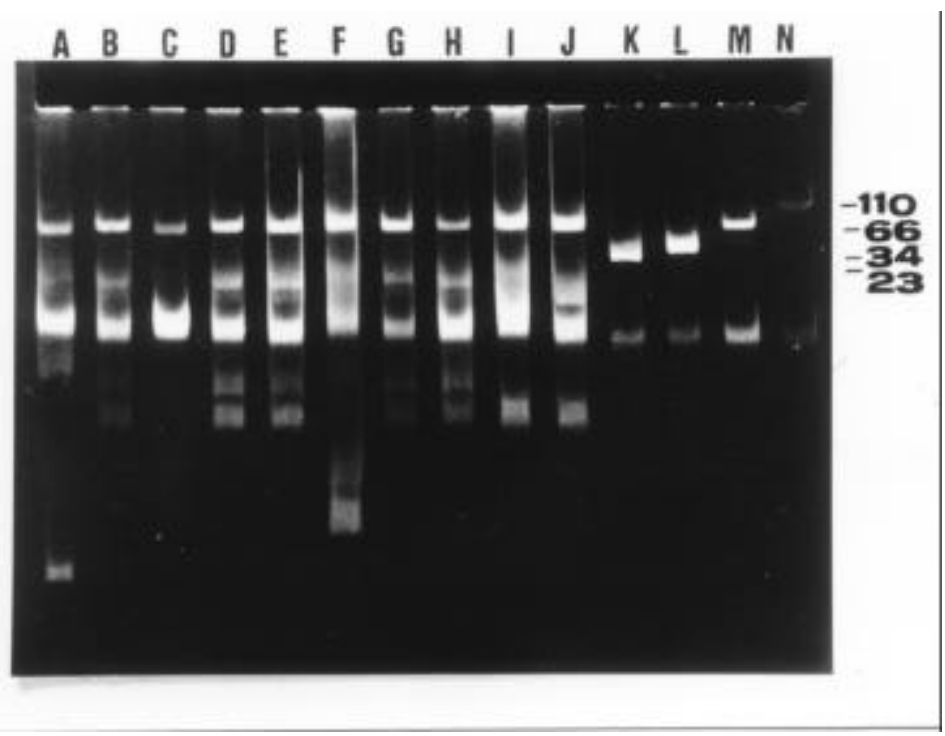

FIG. 2. Agarose gel electrophoresis of Acinetobacter baumannii plasmid DNA extracted by the method of Kado \& Liu (1981). Lane A: strain from enteral solution; Lanes B to J: strains 15 to 19, and 21 to 24, respectively; Lanes K to N, standard plasmids: pSa (23 MDa), RP4 (34MDa), JPN11 (66 MDa), R27 (110MDa).

Table 2. Typing of 17 Acinetobacter baumannii strains isolated from 15 patients bearing hospital acquired infection and from one enteral solution.

\begin{tabular}{|c|c|c|c|c|c|}
\hline $\begin{array}{c}\text { Strain } \\
\text { number }\end{array}$ & $\begin{array}{c}\text { Isolated in } \\
\mathrm{mo} / \mathrm{yr}\end{array}$ & $\begin{array}{l}\text { Sample } \\
\text { Site }\end{array}$ & $\underset{\mathrm{a}}{\text { Biotype }}$ & $\begin{array}{c}\text { Antibiotic } \\
\text { susceptibility }^{\text {pattern }}{ }^{b}\end{array}$ & $\begin{array}{l}\text { Plasmid Profile/ } \\
\text { Molecular mass }\end{array}$ \\
\hline 01 & $4 / 94$ & catheter tip & 2 & B & - \\
\hline 06 & $4 / 94$ & catheter tip & 2 & A & II / $13,04,03$ \\
\hline 09 & $4 / 94$ & catheter tip & 2 & A & II / 05, 04, 03 \\
\hline 10 & $4 / 94$ & catheter tip & 2 & A & II / 05, 03 \\
\hline 11 & $4 / 94$ & catheter tip & 2 & A & II / 13,05 \\
\hline 12 & $4 / 94$ & skin & 2 & A & II / 05, 04, 03 \\
\hline 13 & $6 / 94$ & eyes & 2 & A & - \\
\hline 15 & $6 / 94$ & catheter tip & 19 & B & I / 66, 13 \\
\hline 16 & $6 / 94$ & catheter tip & 19 & B & I / 66 \\
\hline 17 & $6 / 94$ & skin & 19 & B & I / $66,13,05,04$ \\
\hline 18 & $7 / 94$ & catheter tip & 2 & B & I / $66,13,05,04$ \\
\hline 19 & $6 / 94$ & skin & 19 & B & I / $66,13,03,02$ \\
\hline $21^{\mathrm{c}}$ & $8 / 94$ & skin & 2 & B & I / $66,13,05$ \\
\hline $22^{c}$ & $9 / 94$ & skin & 2 & B & I / $66,13,05,04$ \\
\hline 23 & 9/94 & skin & 19 & B & I / $66,13,04$ \\
\hline 24 & 9/94 & catheter tip & 2 & B & I / $66,13,04$ \\
\hline En & $6 / 94$ & enteral solution & 2 & B & I / $66,13,02$ \\
\hline ATCC & - & padrão & 19 & - & - \\
\hline
\end{tabular}

En - strain isolated from enteral solution

a Biotype as determined by Bouvet \& Grimont, 1987.

b Pattern A: Susceptible or intermediate-resistant to Carbenicillin and Amikacin;

Pattern B: Resistant to Carbenicillin and Amikacin; ATCC 14606: control strain

c Same patient 


\section{DISCUSSION}

Strains of A. baumannii are a frequent source of hospital-acquired infections (Beck-Sagué et al., 1990; Harststein et al., 1988). In Brazil, A.baumannii was the most prevalent species (81.6\%) isolated during 1990-1991 at hospitals in Ribeirão Preto City, São Paulo State (Oliveira et al., 1993). All the strains of Acinetobacter analyzed in this study, which were isolated during an outbreak that occurred in 1994 at the University Hospital in Londrina, Paraná State, were identified as A.baumannii. Since Acinetobacter sp has become more prevalent and important as a cause of hospital-acquired infections, a simple method for the epidemiologic characterization of Acinetobacter sp outbreaks should be important for the monitoring and control of such outbreaks. The association of three typing methods employed in this study allowed an adequate characterization of an outbreak by A.baumannii. Antibiotyping and biotyping are largely used by clinical microbiology laboratories for the epidemiologic typing of A.baumannii, but their discriminatory power is low because the majority of clinical isolates are resistant to multiple antibiotics and belong to few biotypes (Dijkshoorn et al., 1993; Seifert et al., 1994b). In agreement with those previous observations, only two biotypes and two antibiotypes were distinguished in this study, and these two markers did not always correlate. However, the association of plasmid profiles with biotypes and antibiotypes allowed the identification of two apparently unrelated outbreaks by A.baumannii, in agreement with the suggestion by Seifert et al. that plasmid profile analysis could be useful in epidemiological typing of A.baumannii (Seifert et al., 1994a; Seifert et al., 1994b). The outbreak that occurred in April was caused by strains that did not carry the 66 Mda plasmid (profile II) and belonged to biotype 2 and antibiotype A; the single exception was a plasmidless strain that presented antibiotype pattern B. On the other hand, the outbreak that occurred from June to September was caused by strains that carried the $66 \mathrm{MDa}$ plasmid (profile I) and presented antibiotype pattern $\mathrm{B}$. These results suggest that the two outbreaks were caused by two different clusters of A.baumannii. However, the possibility cannot be excluded that some strains which caused the first outbreak subsequently acquired the $66 \mathrm{MDa}$ plasmid and participated in the second outbreak (Fig 2). Because the second outbreak occurred during the winter months, and the ratio of skin isolates to catheter tips isolates increased from $0.2(1 / 5)$ in April to $1.2(6 / 5)$ in June to September (Table II), it is possible that another source of infection participated in the second outbreak; this observation might be related to previous reports that contaminated bedding material can be important sources of Acinetobacter sp (Sherertz \& Sullivan, 1985; Seifert et al., 1994b; Bergogne-Bérézin \& Towner, 1996) and corroborates the hypothesis that the second outbreak was caused by a cluster of $A$. baumannii distinct from the first one.

Since all strains, including the two strains that supposedly carry no plasmids, presented multiresistance to drugs, some of the resistance markers of the A.baumannii possibly are chromosomally located, in agreement with previous studies (Bergogne-Bérézin \& Towner, 1996). Nevertheless, $81.8 \%$ (18/22) of the few $(22 / 255)$ occurrences of susceptibility corresponded to strains not harboring the 66 Mda plasmid, which suggests that it participates in the determination of antibiotic resistance. The method of Harstein et al. allowed a better discrimination of the low molecular mass plasmids than the method of Kado \& Liu (Fig. $1 \mathrm{~A}$ and $1 \mathrm{~B}$ ), but no unique correlation between these plasmids and resistance could be ascertained.

The results of this study show that the association of biotyping, antibiotic resistance typing, and plasmid profiles allowed the differentiation of two outbreaks by $A$. baumannii that occurred one shortly after the other and that were at first considered to be a single outbreak, suggesting that these association of methods could routinely be applied for the initial epidemiologic characterization of outbreaks by these bacteria and for monitoring their dissemination in the hospital environment. 


\section{ACKNOWLEDGMENTS}

This work was supported by CNPq (Conselho Nacional de Desenvolvimento Cientîfico e Tecnológico), Brazil. We thank Ms I.B. Kisser for excellent technical assistance.

\section{RESUMO}

Durante um surto ocorrido de abril a setembro de 1994 em um Hospital Universitário, dezesseis cepas de Acinetobacter baumannii foram isoladas de pacientes e uma de solução enteral. Nós posteriormente analizamos as cepas isoladas durante o surto pelos seguintes métodos de tipagem : perfil de DNA plasmidial, perfil de antibiograma e biotipagem. Dois padrões de tipagem foram identificados pela análise do perfil plasmidial. Doze cepas foram caracterizadas como sendo do biotipo 2, e cinco do biotipo 19. O padrão de sensibilidade a amicacina e a carbenicilina possibilitou a classificação das cepas em dois grupos. Os resultados demonstraram que estes três métodos de tipagem associados possibilitaram a diferenciação do que primeiramente foi considerado como um único surto, em dois surtos aparentemente não relacionados.

\section{REFERENCES}

Bauer, A.W.; Kirby, W.M.M.; Sherris, J.C.; Turk, M. (1966), Antibiotic susceptibility testing by a standardized single disk method. Am. J. Clin. Path., 45 (4),p. 493-496, 1966.

Beck-Sagué, C.M.; Jarvis, W.R.; Brook, J.H.; Culver, D.H.; Potts, A.; Gay, E.; Shotts, B.W.; Hill, B.; Anderson, R.L.; Weinstein, M.P. (1990), Epidemic bacteremia due to Acinetobacter baumannii in five intensive care units. Am. J. Epidemiol, 132, 723-733.

Bergogne-Bérézin, E.; Towner, K.J. (1996), Acinetobacter spp as nosocomial pathogens: microbiological, clinical and epidemiological features. Clin. Microbiol. Rev, 9 (2), 148-165.

Bouvet, P.J.M. ; Grimont, P.A.D. (1987) Identification and biotyping of clinical isolates of Acinetobacter. Ann.Inst. Pasteur/ Microbiol. 138, 569-578.

Bouvet, P.J.M.; Jeanjean, S.; Vieu, J.F.; Dijkshoorn, L. (1990) Species, biotype, and bacteriophage type determinations compared with cell envelope protein profiles for typing Acinetobacter strains. J. Clin. Microbiol., 28, 170-176.

Dijkshoorn, L.; Wubbels, J.L.; Beunders, A.J.; Degener, J.E.; Boks, A.L. (1989) Use of protein profiles to identify Acinetobacter calcoaceticus in a respiratory care unit. J.Clin.Pathol., 42, 853-857.

Dijkshoorn, L.; Aucken, H.M.; Gerner-Smidt, P.; Kaufmann, M.E.; Ursing, J.; Pitt, T.L. (1993) Correlation of typing methods for Acinetobacter isolates from hospital outbreaks. J. Clin. Microbiol., 31, 702-705.

Gerner-Smidt, P. (1992) Ribotyping of the Acinetobacter calcoaceticus - Acinetobacter baumannii complex. J. Clin. Microbiol., 30, 2680-2685.

Gouby, A.; Carles-Nurit, M.; Bouziges, N.; Bourg, G.; Mesnard, R.; Bouvet, P.M.J. (1992) Use of pulse-field gel eletrophoresis for investigation of hospital outbreaks of Acinetobacter baumannii. J. Clin. Microbiol., 30, 1588-1591.

Graser, Y.; Klare, I.; Halle, R.; Gantenberg, R.; Buchholz, P.; Jacobi, H.D.; Presber, W.; Schonian, G. (1993) Epidemiological study of an Acinetobacter baumannii outbreak by using polymerase chain reaction fingerprinting. J. Clinical Microbiol., 31, 2417-2420, .

Harststein, A.I.; Rashad, A.L.; Liebler, L.M.; Actis, L.A.; Freeman. J.; Rourke, J.W.; Stibolt, T.B.; Tolasky, M.; Ellis, G.R.; Crosa, J.H. (1988) Multiple intensive care unit outbreak of Acinetobacter calcoaceticus subspecie anitratus respiratory infection and colonization associated with contaminated reusable ventilator circuits and resuscitation bags., Am. J. Med., 85, 624-631.

Hartstein, A.I.; Morthland, V.H.; Rourke, J.W.; Freeman, J.; Garber, S.; Sykes, R.; Rashad, A.L. (1990), Plasmid DNA fingerprinting of Acinetobacter calcoaceticus subspecies anitratus from intubated and mechanically ventilated patients. Infect. Control. Hosp.Epidemiol., 11, 531-538. 
Kado, C.; Liu, S.T. (1981), Rapid procedure for detection and isolation of large and small plasmids. J.Bacteriol., 145, 1365-1373,

Muller-Serieys, C.; Lesowoy, J.B.; Perez, E.; Fichelle, A.; Boujeois, B.; Joly-Guillou, M.L.; Bergogne-Bérézin, E. (1989) Infections nosocomiales à Acinetobacter epidemiologie et difficultés thérapeutiques. Présse Med., 18, 107-108.

Oliveira, M.G.; Vaz, T.M.I.; Gonçalves, C.R.; Irino, K.; Levy, C.E (1993), Acinetobacter species in clinical isolates and detection of a new biotype of Acinetobacter baumannii. Rev.Microbiol.., 24, 215-221.

Ramphal, R.; Kluge, R. (1979) Acinetobacter calcoaceticus variety anitratus: an increasing nosocomial problem. Am. J. Med. Sci., 277, 57-66.

Reboli, A.C.; Houston, E.D.; Monteforte, J.S.; Wood, G.A.; Hamill, R.J. (1994) Discrination of epidemic and sporadic isolates of Acinetobacter baumannii by repetitive element PCR-mediated DNA fingerprinting. J. Clin. Microbiol., 32, 26352640.

Sahm, D.F.; Washington J.A. II, (1991), Antibacterial susceptibility tests: dilution methods. In - Manual of clinical Microbiology. , ed. A. Ballows, Copyright, American Society for Microbiology, Washington D.C , 5 ed, p. 1105-1116.

Santos-Ferreira, M.O.; Vieu, J.F.; Klein, B. (1984), Phage-types and susceptibility to 26 antibiotics of nosocomial strains of Acinetobacter isolated in Portugal. J. Int. Med. Res., 12, 364-368.
Seifert, H.; Boullion, B.; Pulverer, G. (1994a) Plasmid DNA profiles of Acinetobacter baumannii: clinical application in a complex endemic setting. Infec. Control. and Hosp. Epidemiol.,15, 520-528.

Seifert, H.; Schulze, A.; Baginski, R.; Pulverer, G. (1994b) Comparison four diffrent methods for epidemiologic typing of Acinetobacter baumannii. J. Clin. Microbiol, 32(7), 1816-1819.

Seifert, H.; Gerner-Smidt, P. (1995) Comparison of ribotynpig and pulsed-field gel electrophoresis for molecular typing of Acinetobacter isolates. J. Clin. Microbiol.,. 33 (5), 1402-1407.

Sherertz, R.J.; Sullivan, M.L. (1985). An outbreak of infectins with Acinetobacter calcoaceticus in burn patients: contamination of patients mattresses. J. Infect. Dis., 151, 252-258.

Tjernberg, I.; Ursing, J. (1989) Clinical strains of Acinetobacter classified by DNA-DNA hybridization. APMIS, 97, 595-605.

Traub, W.H.; Spohr, M. (1994) Serotyping of Acinetobacter baumannii and genospecies 3: an update. Med Microbiol. Lett., 3, 120-127.

Vila, J.; Almela, M., Jimenez de Anta, M.T. (1989), Laboratory investigation of outbreak caused by two different multiresistant Acinetobacter calcoaceticus subsp anitratus strains. J. Clin. Microbiol., 27, 1086-1089.

Weernink, A.; Sevenin, W.P.J.; Tjernberg, I.; Dijkshoorn, L. (1995) .Pillows, an unexpected source of Acinetobacter. $J$. Hosp. Infect., 29,189-199. 